\title{
Study of Atresia and Its Changes in the Ovary during the Annual Reproductive Cycle of a Wild Avian Species, the Yellow-Throated Sparrow (Petronia xanthocollis Burton)
}

\author{
Ganapathy Bhat*, and Biswaranjan Maiti**
}

\begin{abstract}
Atresia and its changes during the annual ovarian cycle were studied histologically and histochemically (sudanophilic lipids and $3 \beta$-HSDH) in the ovary of the Indian yellow-throated wild sparrow (Petronia xanthocollis Burton).

Study of atresia from serial sections of the ovary revealed that there were basically two types of atresia: non-bursting (lipoidal and cystic) and bursting (Types I, II and III). Non-bursting atresia was observed mostly in the primordial follicles, and bursting type exclusively in the larger follicles.

Sudanophilic lipid was abundant in the lipoidal atresia but negligible in the cystic type. In the bursting atresia, lipid was negligible in early stage especially in the thecal glands but abundant in later stages. $3 \beta$-HSDH activity was absent in the non-bursting atresia, but present in the bursting atresia (early stage).

Annual study of atresia showed that the non-bursting atresia was common and its frequency was higher than the bursting atresia throughout the year. The frequency of both non-bursting and bursting atresia increased during the progressive phase, became maximum in breeding and decreased during regression and non-breeding phases of the annual ovarian cycle. Lipid was maximum in breeding and regression phase, but $3 \beta$-HSDH activity was highest only during breeding compared to other phases of the reproductive cycle.
\end{abstract}

Key words: Atresia, Ovary, $3 \beta$-hydroxysteroid dehydrogenase, Lipid, Annual Reproductive Cycle, Yellow-throated sparrow

\section{Introduction}

There is some information relating to the types of atresia in poultry birds. Davis $(1942,1944)$ observed only bursting atresia in the hen ovary, but Deol (1955) described three types of atresia in the fowl ovary. In the Indian domestic duck, five types of atresia: glandular, lipoglandular, yolky liquefying, yolky blood follicle and yolky bursting were recognized (Pal 1980). Information is also available on atresia in wild birds. Marshall and Coombs (1957) reported two types of atresia (lipoidal and non-lipoidal) in the rook ovary. Dominic (1961) found bursting atresia, in situ atresia and cystic atresia in the pigeon ovary. But glandular, lipoglandular and yolky types were reported in the black-billed magpie (Erpino 1969) and house-crow (Ambadkar \& Chauhan 1977). These authors suggested that the lipoglandular atresia represents the later stages of the other

\footnotetext{
Received 22 August 1992, Rivised 5 January 1993, 2nd Rivision 11 January 1994, Accepted 30 May 1994.

* Histophysiology Laboratory, Department of Zoology, University of Calcutta, 35 Ballygunge Circular Road, Calculla 700 019, India.

** To whom reprint requests should be sent.
} 
two. Subsequently, five types of atresia: normal bursting, lipoidal, lipoglandular, glandular and liquefying atresia were recognized in the ovaries of the white-crowned sparrow (Kern 1972) and pied-flycatcher (silverin 1980). Guraya (1976a) and Guraya and Chalana (1976) described primordial follicles in atresia, previtellogenic follicles in atresia and vitellogenic follicles in atresia in the columbid and house-sparrow ovaries. Gupta and maiti (1986) studied atresia from serial sections of the ovary and reported mainly two types of atresia, non-bursting (lipoidal and cystic) and bursting (with 6 types: I-VI), in the pied myna ovary. Histogenesis of the atretic follicles and their fate were described in the seasonally breeding scrub jay, Aphelocoma coerulescens by Erpino (1973) and he suggested that the diverse histology of avian atretic follicles reflects different stages in the process of atresia rather than their multiple origin-a view not shared by other workers.

Seasonal fluctuation in the frequency of atretic follicles has been reported for few avian species. Follicles become atretic as the breeding season approaches and become most abundant immediately after egg laying (Marshall \& Coombs 1957, Erpino 1969, 1973, Kern 1972, Guraya \& Chalana 1976, Ambadkar \& Chauhan 1977). Glandular and yolky atresia are maximum during egg laying, but lipoglandular atresia is most abundant during the nestling period (Erpino 1969, Ambadkar \& Chauhan 1977). Kern (1972) recorded normal bursting and glandular atresia being common during prelaying and laying, lipoglandular during incubation and nesting, and lipoidal and liquefying atresia during nestling and post breeding periods. Guraya \& Chalana (1976) found maximum atresia in primordial follicles in winter, previtellogenic follicles during breeding and vitellogenic follicles during post breeding.

Activity of $3 \beta$-hydroxysteroid dehydrogenase ( $3 \beta$-HSDH) has been noticed in the atretic follicles but it soon disappears suggesting a loss of steroidogenic potentiality (Sayler et al. 1970, Saidapur 1978, Bhujle et al. 1979a, b). Guraya (1976a) believed that the granulosa cells of atretic follicles undergo abortive luteinization and do not appear to secrete steroid hormones. Contrarily, Saidapur (1978) expressed the opinion that a transient steroidogenic potentiality of granulosa cells in a large number of atretic follicles of any given time cannot be neglected.

It is apparent from the above literature that the problems relating to the types of atresia, and their changes during the annual reproductive cycle have not been adequately resolved. Precise objectives of the present investigation were to ascertain the occurrence of atresia during follicular development, significance of atresia and their frequency during the annual reproductive cycle especially in wild birds. Thus, in the current article, these topics have been explored in the ovary of a wild avian species, the yellow-throated sparrow.

\section{Materials and Methods}

Adult female specimens of the Indian yellow-throated wild sparrow, Petronia xanthocollis Burton (Order: Passeriformes, Family: Ploceidae, Sub-family: Passerinae), were collected once a month throughout the year from North India (Varanasi, Uttar Pradesh) and were killed by cervical dislocation 24 hours after their capture. Body weight was 
Atresia and its Changes in the Ovary during the Annual Reproductive Cycle of a Wild Avian Species 117

Table 1. Annual changes in the incidence of atresia in the ovary of the sparrow

\begin{tabular}{lcccc}
\hline \hline & & & \multicolumn{2}{c}{ Atresia (\%) } \\
\cline { 3 - 5 } Month of observation & Healthy follicles (\%) & Non-bursting & Bursting \\
\hline January & $(7)$ & $78.74 \pm 1.97^{*}$ & $20.71 \pm 2.01$ & $0.55 \pm 0.08$ \\
February & $(8)$ & $72.45 \pm 3.29$ & $26.76 \pm 3.48$ & $0.79 \pm 0.19$ \\
March & $(10)$ & $71.47 \pm 2.21$ & $27.24 \pm 2.24$ & $1.29 \pm 0.24$ \\
April & $(10)$ & $60.26 \pm 0.83$ & $36.87 \pm 0.85$ & $2.87 \pm 0.11$ \\
May & $(10)$ & $64.06 \pm 2.57$ & $35.77 \pm 2.63$ & $0.28 \pm 0.06$ \\
June & $(8)$ & $79.77 \pm 1.95$ & $20.18 \pm 1.99$ & $0.19 \pm 0.04$ \\
July & $(8)$ & $83.08 \pm 5.39$ & $16.69 \pm 5.32$ & $0.23 \pm 0.05$ \\
August & $(6)$ & $84.12 \pm 2.66$ & $15.74 \pm 2.80$ & $0.14 \pm 0.05$ \\
September & $(6)$ & $78.65 \pm 1.37$ & $21.35 \pm 1.37$ & - \\
October & $(5)$ & $79.59 \pm 2.63$ & $20.41 \pm 2.66$ & - \\
November & $(6)$ & $78.25 \pm 2.83$ & $21.70 \pm 2.68$ & $0.05 \pm 0.01$ \\
December & $(8)$ & $80.33 \pm 1.85$ & $19.60 \pm 1.86$ & $0.07 \pm 0.02$ \\
ANOVA & & $\mathrm{p}<.05$ & $\mathrm{p}<.05$ & $\mathrm{p}<.01$ \\
\hline
\end{tabular}

Figures in parentheses showing number of specimens.

*: Mean \pm Standard Error.

- : Absent.

Table 2. Histochemical studies ${ }^{1}$ of lipid and $3 \beta-H S D H$ in the atretic follicles of the ovary during annual reproductive cycle of the sparrow

\begin{tabular}{|c|c|c|c|}
\hline \multicolumn{2}{|c|}{$\begin{array}{l}\text { Month of } \\
\text { observation }\end{array}$} & \multirow{2}{*}{$\begin{array}{c}\text { Lipid } \\
\text { (Thecal gland cells) } \\
\frac{\text { Atretic follicle }^{2}}{H}\end{array}$} & \multirow{2}{*}{$\begin{array}{l}3 \beta \text {-Hydroxysteroid dehydrogenase } \\
\frac{\text { (Thecal gland cells) }}{\text { Atretic follicle }{ }^{3}} \\
+\end{array}$} \\
\hline January & (4) & & \\
\hline February & (4) & H & + \\
\hline March & (5) & H & H \\
\hline April & (4) & m & H \\
\hline May & (4) & m & + \\
\hline June & (5) & H & - \\
\hline July & (4) & H & - \\
\hline August & (5) & - & - \\
\hline September & (5) & - & - \\
\hline October & (5) & - & - \\
\hline November & (5) & - & - \\
\hline December & (5) & + & - \\
\hline
\end{tabular}

Figures in the parentheses indicate number of birds.

1: Visual rating of intensity of reaction (-: Negative; + : Weak; H: Moderate; H: Intense).

2: Includes non-bursting (lipoidal) and late bursting atresia.

3: Representing early stages of bursting atresia.

recorded at autopsy. Ovary (left being functional) was dissected out, weighed by a torsion balance (Roller-Smith, U.S.A), fixed in Bouin's fluid and processed for routine microtomy. Serial paraffin sections $(25 \mu \mathrm{m})$ of the ovary were prepared for identification of different types of atresia and for ascertaining their changes during the annual ovarian 
cycle. Few thin sections $(5 \mu \mathrm{m})$ of the ovary were prepared for detailed histological study. All the sections were stained by Masson's trichrome method. Atretic follicles were identified by the method of Erpino (1969). All healthy and atretic follicles were counted from serial sections of each ovary and their percentage were determined. These parameters were studied from the same specimens (Table 1). Sudanophilic lipids (Pearse 1968) and $3 \beta$-hydroxysteroid dehydrogenase ( $3 \beta$-HSDH) (Pearse 1972) were studied histochemically from the ovaries (left) of other specimens (Table 2). For enzymatic study, 15 $\mu \mathrm{m}$ thick unfixed cryostat sections were prepared and incubated withe dehydroepiandrosterone (DHEA) as substrate. Control sections were incubated without the substrate. All data relating to the frequency of healthy and atretic follicles were analysed statistically by one-way analysis of variance (ANOVA) (Scheffe 1961, Snedecor and Cochran 1971).

\section{Results}

\section{A. Histology}

There were two main types of atresia: (i) non-bursting and (ii) bursting types studied from serial sections of the ovary.

\section{(i) Non-bursting atresia}

It was common in primordial follicles. The follicular wall was not ruptured. Non-bursting atresia was of two types (lipoidal and cystic).

a) Lipoidal atresia: It was found in the primordial follicles less than $250 \mu \mathrm{m}$ in diameter. The ooplasm contained an enormous amount of lipid materials represented by vacuoles in histological preparation (Fig. 1).

b) Cystic atresia: It was common in the primordial follicles less than $500 \mu \mathrm{m}$ in diameter, but rarely found in small developing follicles. The granulosa layer was detached along with the basement membrane from one side of the follicle and pushed inside the follicle (Fig. 3). Lipids were rarely seen in the ooplasm of these follicles.

\section{(ii) Bursting atresia}

It was common in the follicles larger than $500 \mu \mathrm{m}$ in diameter (small developing,

Fig. 1. Section of the ovary showing non-bursting lipoidal (L) atresia in the yellow-throated sparrow. Masson's trichrome stain. $\times \mathbf{4 0 0}$.

Fig. 2. Non-bursting lipoidal atresia (arrow) loaded with sudanophilic lipids. Sudan black B reaction. $\times 400$.

Fig. 3. Section of the ovary showing many non-bursting cystic (c) atresia. Note the oocyte with the granulosa layer detached from one side of the follicle. Masson's trichrome stain. $\times 100$.

Fig. 4. Initial stage of bursting atresia (type I) showing ruptured site (arrow) in the follicle and extruded follicular (F) material in the surrounding stroma. Masson's trichrome stain . $\times 100$.

Fig. 5. Magnified view of figure 4 showing hypertrophied thecal cells (T) with scanty gland cells, and multilayered granulosa $(G)$ with degenerated cells; some of them are desquamated in the ooplasm (arrows). Masson's trichrome stain. $\times 400$. 

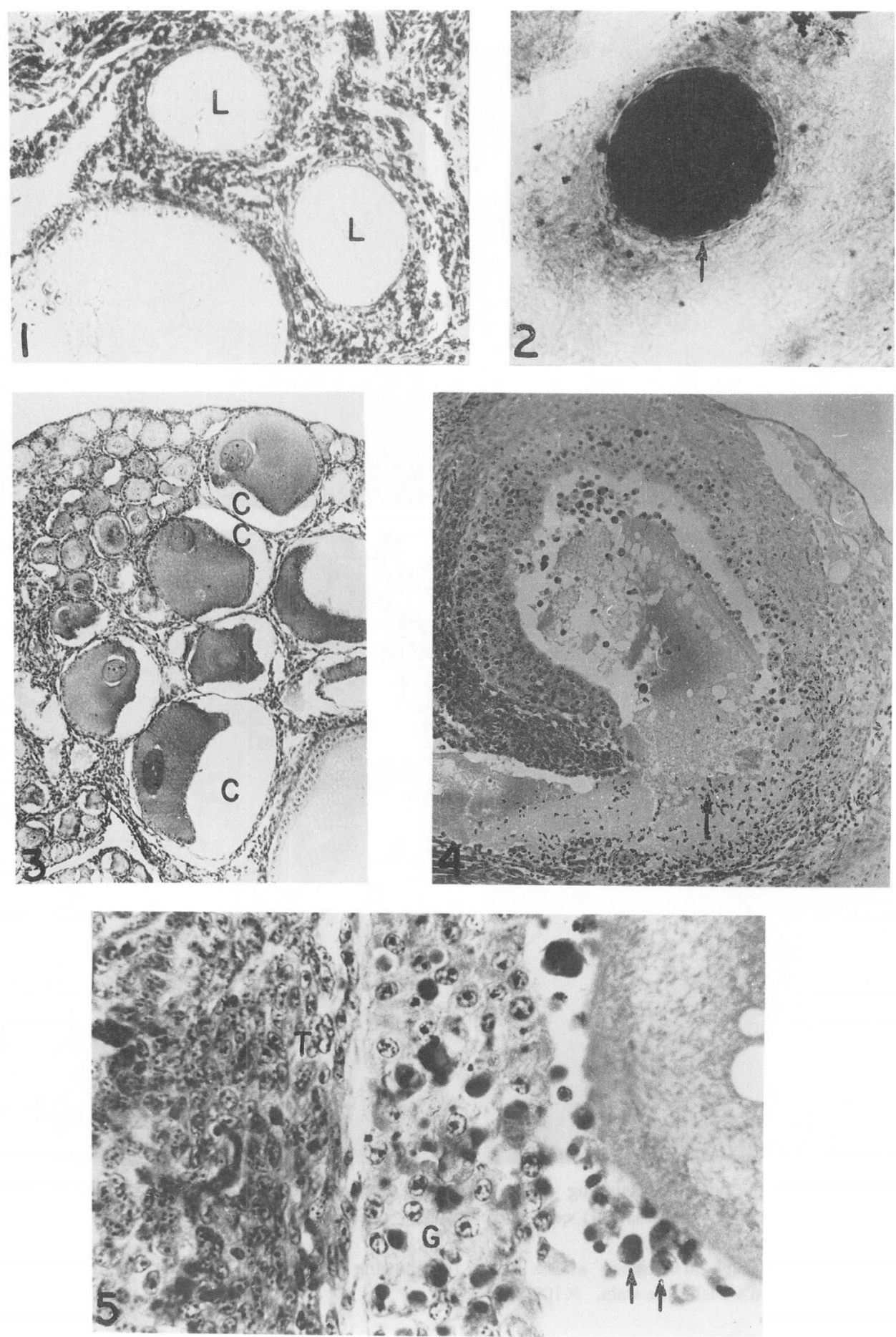

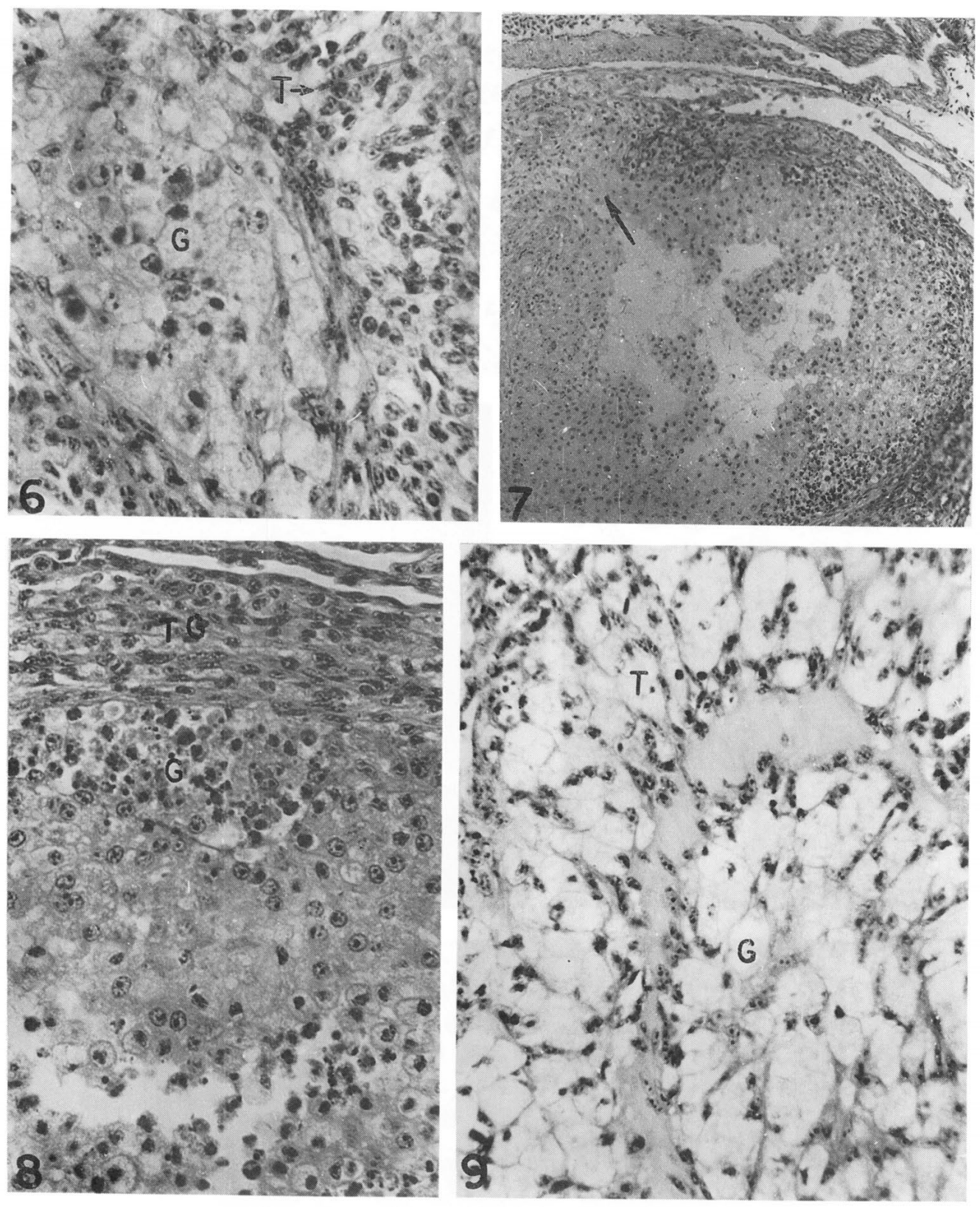

Fig. 6. The later stage of bursting atresia (type I) showing reduced follicular size with highly degenerated granulosa $(G)$ cells surrounded by degenerated thecal $(T)$ cells. Masson's trichrome stain. $\times 400$.

Fig. 7. Initial stage of bursting atresia (type II) showing ruptured site (arrow) in the follicle. Massion's trichrome stain. $\times 100$. 
large developing and yolky follicles). They had ruptured follicular wall. The follicular contents were extruded into the surrounding stroma. The bursting site was single and small, and was directed towards the stroma of the ovary. The atretic follicles retained their follicular identity for a long time and always remained attached with the germinal epithelium of the ovary. They had multilayered granulosa without mitotic cells. Histologically, three types of bursting atresia were recognized as described in the following.

Type ' $I$ ': It was found generally in the small developing follicles. At the initial stage, the follicular size was small, with multilayered granulosa showing pycnotic cells in its inner layer. Cells from inner layer of granulosa were extruded into the follicular lumen. The thecal cells were hypertrophied and the thecal gland cells were scanty (Figs. 4 and 5). In the later stage of atresia, the follicular size was greatly reduced representing few degenerated granulosa cells surrounded by degenerated thecal elements (Fig. 6).

Type 'II': It was observed in the large developing and early yolky follicles. During early stage of atresia, the histological features were similar to those of type I, except that the granulosa layer was thicker than type I (Figs. 7 and 8), and the thecal layers were vascularized with numerous hypertrophied and few mitotic cells compared to those of type I. Moreover, cells from inner layer of granulosa and follicular ooplasm were extruded from the follicle and invaded the surrounding stroma. Abundant thecal gland cells were present in both the thecal layers (Fig. 8). In the later stage, the follicular size was further reduced containing numerous degenerated ex-granulosa cells surrounded first by a layer of fibroblast cells and subsequently by a layer of degenerating thecal cells (Fig. 9).

Type 'III': It was common in heavily yolked follicles. In the early stage, it was similar to that of type II but the granulosa layer was thin (3-4 cell layers) (Fig. 10) containing degenerated cells which engulfed yolky materials in type III. The degenerated granulosa cells with yolky materials and follicular ooplasm were extruded and invaded the surrounding stroma (Fig. 11). The thecal cells were not hypertrophied and the gland cells were scanty. In the later stage of atresia, the follicular size was further decreased containing only a central mass of ex-granulosa cells surrounded by a very thick layer of collagendous fibres (Fig. 12).

\section{B. Histochemistry}

i) Non-bursting atretic follicles

a) Lipid: The lipoidal atretic follicles showed abundance of sudanophilic lipids in the ooplasm (Fig. 2). In the cystic follicles, a negligible amount of lipid was

Fig. 8. Magnified view of figure 7 showing large number of thecal gland (TG) cells and multilayered degenerated granulosa (G) cells. Masson's trichrome stain. $\times 400$.

Fig. 9. The later stage of bursting atresia (type II) showing reduced follicular size with extremely degenerated granulosa (G) cells surrounded by extremely degenerated thecal (T) cells. Masson's trichrome stain. $\times 400$. 
found in the ooplasm.

b) $3 \beta-H S D H: 3 \beta-H S D H$ activity was absent in both lipoidal and cystic atretic follicles.

ii) Bursting atretic follicles

a) Lipid: Sudanophilic lipid was scanty in the ooplasm and thecal gland cells of the atretic follicle during early stage of atresia, but was abundant in both the areas during the later stage of atresia.

b) $3 \beta-H S D H: 3 \beta-H S D H$ reaction in the thecal gland cells was moderate in the early stage but absent in the later stage of atresia.

\section{Changes in atresia during the annual ovarian cycle}

\section{A. Histology}

Non-bursting atresia (lipoidal and cystic types) was more common and its frequency was higher than those of bursting atresia throughout the annual ovarian cycle of the yellow-throated sparrow. The frequency of both non-bursting and bursting atresia increased during the progressive phase (January through March), became maximum during breeding (April) and decreased during other phases (regression: May and June, and non-breeding: July through December) of the ovarian cycle (Table 1). The bursting atresia was negligible or absent especially in the late non-breeding phase (Table 1).

\section{B. Histochemistry}

a) Lipid: The intensity of sudanophilic lipid reaction was moderate during the progressive phase, became intense during breeding and regression phases, and was negligible or absent during the non-breeding phase (Table 2).

b) $3 \beta-H S D H: 3 \beta-H S D H$ activity gradually increased during the progressive phase, became maximum during breeding and was negligible or absent in other phases (Table 2).

\section{Discussion}

Follicular atresia, studied from serial sections of the ovary, is common during all the phases of the annual ovarian cycle of the yellow-throated sparrow. Atresia is basically of two types: non-bursting (lipoidal and cystic) and bursting. The former type is found in the primordial follicles and the latter in the small developing, large developing and yolky follicles. Non-bursting atresia is more common and its population is also higher than those of the bursting type. Thus, it appears that atresia occurs more frequently in earlier stages of follicular development (premature follicles) than in the late developmental stage (mature follicles), thereby indicating that in the sparrow the premature follicles are more suceptible to degeneration (atresia) than the mature type. The differential responses of premature and mature follicles to atresia however, are yet to be ascertained.

Guraya \& Chalana (1976) have suggested that lipids in the atretic follicles contribute precusor material for steroid biosynthesis in the house-sparrow. The present findings 

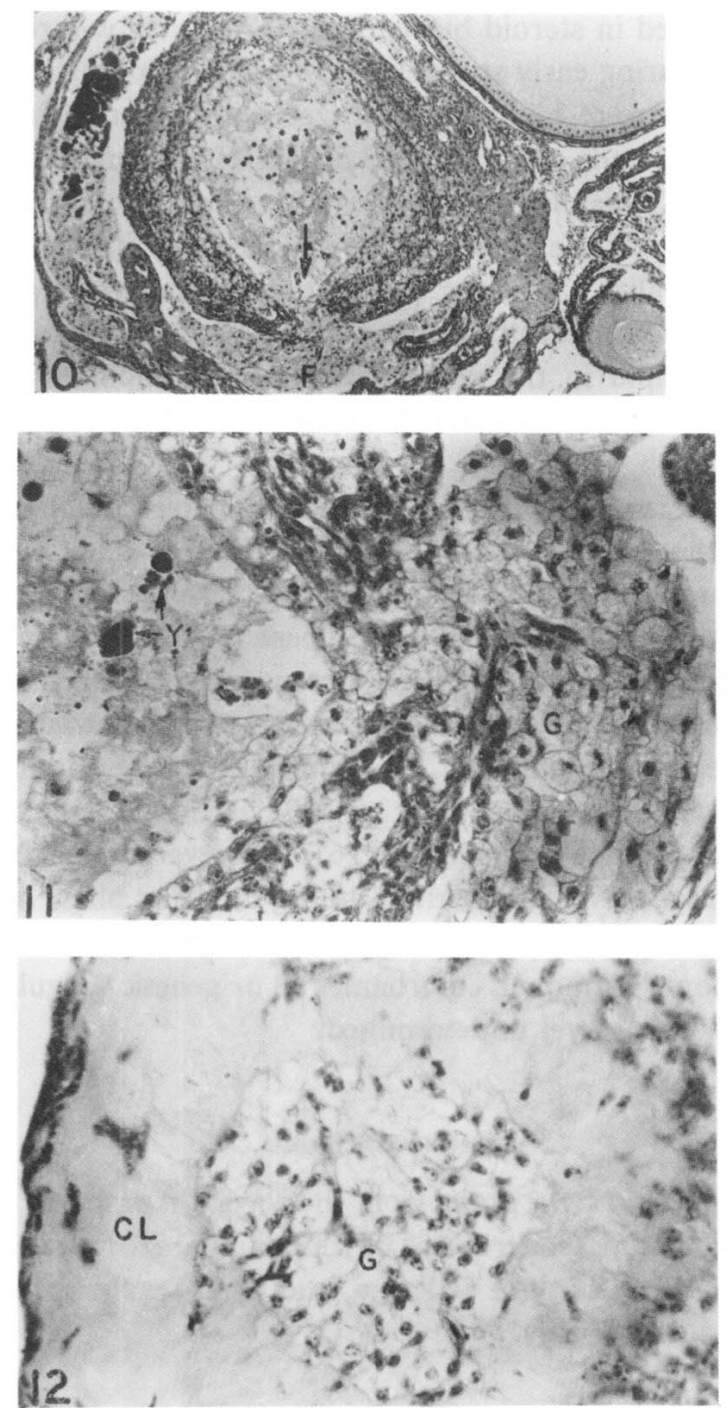

Fig. 10. Initial stage of bursting atresia (Type III) showing ruptured site (arrow) in the follicle and extruded follicular (F) material invaded in the surrounding stroma. Masson's trichrome stain. $\times 100$.

Fig. 11. High power view of figure 10 showing degenerated yolk (Y) material in the follicular ooplasm. Degenerated granulosa $(G)$ cells are seen outside the follicle. Masson's trichrome stain. $\times \mathbf{4 0 0}$.

Fig. 12. The later stage of bursting stresia (type III) showing extremely reduced follicles with a central mass of extremely degenerated granulosa $(G)$ cells surrounded by a very thick collagen layer (CL). Masson's trichrome stain. $\times 400$.

indicate that the lipoidal atresia contained an abundance of sudanophilic lipids, but failed to show $3 \beta-\mathrm{HSDH}$, thereby suggesting that sudanophilic lipids of at least the lipoidal 
atresia may not be involved in steroid biosynthesis in the yellow-throated sparrow. But bursting atresia at least during early stages (types I and II) appear to have steroidogenic potential since their theca were highly vascularized with hypertrophied thecal cells and abundance of thecal gland cells. Moreover, $3 \beta-\mathrm{HSDH}$ was present in the theca of the bursting atresia. But these histological features as well as $3 \beta-\mathrm{HSDH}$ activity were not observed in the later stage of the bursting atresia (type III), thereby suggesting loss of their steroidogenic potentiality. Saidapur (1978) has also suggested a transient steroidogenic potentiality of the avian atretic follicles. However, the significance of the huge amount of sudanophilic lipid in the non-bursting atresia (lipoidal) and the nature of steroids in the bursting atresia (types I and II) in the ovary of the yellow-throated sparrow remain unknown.

Annual study of atresia reveals that the non-bursting atresia, unlike the bursting type, is present throughout the annual ovarian cycle and the frequency of the former is also significantly higher than the latter throughout the cycle. Moreover, the frequency of both types of atresia increases during the progressive phase (January-March), becomes maximum during breeding (April) and declines subsequently in other phases (regression: May-August and non-breeding: September-December) of the ovarian cycle (Bhat 1984). Thus, frequency of atresia varies annually, that coincides with the annual ovarian cycle in the yellow-throated sparrow like that of other wild birds (Marshall \& Coombs 1957, Erpino 1969, Kern 1972, Guraya \& Chalana 1976). However, higher frequency of atresia during pre-breeding (progressive) and highest during breeding phase of the ovarian cycle could be due to initiation of maximum number of follicles that underwent development for ovulation. But the factors (hormonal, environmental or genetic) regulating atresia in the yellow-throated sparrow are as yet undetermined.

\section{Acknowledgements}

This work was supported by a grant from the special Assistance Programme of the University Grants Commission, Government of India, to the Histophysiology Laboratory, Department of Zoology, University of Calcutta, and by a Teaching Fellowship Grant of the U.G.C to the first author (GB).

\section{References}

Ambedkar, P. M. \& Chauhan, B. C. (1977). Observations on reproductive cycle of Indian house crow, Corvus splendens (Vieillot). II. The annual ovarian cycle-A histomorphological and field study. Pavo 15: 48-72.

Bhujle, B. V., Nadkarni, V. B. \& Rao, M. A. (1979a). Steroid synthesizing cells in the embryonic and adult gonads of the domestic pigeon, Columba livia (Gmelin). Gen. Comp. Endocrinol. 38: 153-161.

Bhujle, B., Nadkarni, V. B. \& Rao, M. A. (1979b). Steroid synthesizing cellular sites in the ovary of the domestic pigeon Columba livia (Gmelin)-histochemical study. Histochem. J. 11: 253-266.

Davis, D. E. (1942). The bursting of avian follicles at the beginning of atresia. Anat. Rec. 82: 153-165.

Davis, D. E. (1944). The occurrence of burst atretic follicles in birds. Anat. Rec. 90: 307-309.

Deol, G. S. (1955). Studies on the structure and function of the ovary of the domestic fowl (with reference to the correlation of cell changes with physiological activity). Ph. D. Thesis. University of Edinburgh.

Dominic, C. J. (1961). A study of the atretic follicles in the ovary of the domestic pigeon. Proc. Nat. Acad. Sci. 
Atresia and its Changes in the Ovary during the Annual Reproductive Cycle of a Wild Avian Species 125

India 31: 273-286.

Erpino, M. J. (1969). Seasonal cycle of reproductive physiology in the black-billed magpie. Condor 71: 267279.

Erpino, M. J. (1973). Histogenesis of atretic ovarian follicles in a seasonally breeding bird. J. Morphol. 139: $239-250$.

Gupta, S. K. \& Maiti, B. R. (1986). Study of atresia in the ovary during the annual reproductive cycle and nesting cycle of the pied myna. J. Morphol. 190: 285-296.

Guraya, S. S. (1976a). Morphological and histochemical observations on follicular atresia and interstitial gland tissue in the Columbid ovary. Gen. Comp. Endocrinol. 30: 534-538.

Guraya, S. S. (1976b). Recent advances in the morphology, histochemistry and biochemistry of steroidsynthesizing cellular sites in the nonmammalian vertebrate ovary. Int. Rev. Cytol. 44: 365-409.

Guraya, S. S. \& Chalana, R. K. (1976). Histochemical observations on the seasonal fluctuations in the follicular atresia and interstitial gland tissue in the house sparrow ovary. Poult. Sci. 55: 1881-1885.

Kern, M. D. (1972). Seasonal changes in the reproductive system of the female white-crowned sparrow, Zonotrichia leucophrys gambelii in captivity and in the field. 1. The ovary. z. Zellforsch. 126: 297-319.

Marshall, A. J. \& Coombs, C. J. F. (1957). The interaction of environmental, internal and behavioural factors in the rook (Corvus $f$. frugilegus) Linnaeus. Proc. Zool. Soc. London 128: 545-589.

Pal, D. (1980). Histophysiology of reproduction in the domestic duck. Ph. D. Thesis, University of Calcutta.

Pearse, A. G. E. (1968). Histochemistry, theoretical and applied. 3rd ed., Vol. 1. Churchill Livingstone. Edinburgh, London and New York, 759 p.

Pearse, A. G. E. (1972). Histochemistry, theoretical and applied. 3rd ed., Vol. 2. Churchill Livingstone. Edinburgh, London and New York, 1518 p.

Saidapur, S. K. (1978). Follicular atresia in the ovaries of nonmammalian vertebrates. Int. Rev. Cytol. 54: 225241.

Sayler, A., Dowd, A. J. and Wolfson, A. (1970). Influence of photoperiod on the localization of $\Delta^{5}$ $3 \beta$-hydroxysteroid dehydrogenase in the ovaries of maturing Japanese quail. Gen. Comp. Endocrinol. 15: 20-30.

Seheffe, H. (1961). The Analysis of variance. John Wiley. New York, London.

Silverin, B. (1980). Seasonal development of reproductive organs in the female pied fiycatcher Ficedula hypoleuca and experimental studies on duration of her re-nesting ability. J. Zool. London 190: 241-257.

Snedecor, G. W. \& Cochran, W. G. (1971). Statistical Methods, 7th ed. Iowa State University Press. Ames.

\section{ミヤマホオジロの卵巣内閉鎖沪胞の解析とその周年変化に関する研究}

ミヤマホオジロの卵巣内閉鎖沪胞とその周年変化について，組織学的および組織化学的に調べた。組織 学的解析により，この鳥類の閉鎖汇胞には侵入性閉鎖と破裂性閉鎖の二型が存在することがわかった。侵 入性閉鎖汇胞は原始卵胞に, 破裂性閉鎖卵胞は大型卵胞に, それぞれ多く見られた。スダン陽性反応は, 脂 肪の多い汇胞では検出されたが, 衰状沪胞にはほとんど認められなかった。破裂性閉鎖沪胞中の脂肪は, 初 期の段階ではほとんど存在しなかったが，末期の段階で著しく増加した。3 $\beta$-水酸基脱水素酵素活性は侵入 性閉鎖沪胞には無く，初期の破裂性閉鎖沪胞に検出された。

年間を通じて，侵入性閉鎖沪胞は破裂性のものに較べ高頻度に見られた。侵入性閉鎖沪胞と破裂性閉鎖 汇胞の出現頻度は共に, 卵巣の発達期に増加し, 成熟期に最大を示した後, 退化期に減少した。脂質は成熟 期と退化期に最大となり， $3 \beta$-水酸基脱水素酵素活性は成熟期のみ高値を示した。

（文責 筒井和義）

Ganapathy Bhat and Biswaranjan Maiti: カルカッタ大学動物学科組識生理学教室 